\title{
Refractory Hypotension after Successful Cardiac Arrest Resuscitation- Time to Rule Out Vasoplegic Syndrome
}

\author{
Suresh J. ${ }^{1}$, Balaji T.2 , Santhosh V. ${ }^{3}$, Nithish Mukunthan M.4, Rajaram Manoharan ${ }^{5}$ \\ ${ }^{1}$ Department of Anaesthesiology and Critical Care, Preethi Hospitals (P) Ltd., Madurai, Tamilnadu, India. \\ ${ }^{2}$ Department of Anaesthesiology and Critical Care, Preethi Hospitals (P) Ltd., Madurai, Tamilnadu, India. \\ ${ }^{3}$ Department of Anaesthesiology and Critical Care, Preethi Hospitals (P) Ltd., Madurai, Tamilnadu, India. \\ ${ }^{4}$ Department of Anaesthesiology and Critical Care, Preethi Hospitals (P) Ltd., Madurai, Tamilnadu, India. \\ ${ }^{5}$ Department of Anaesthesiology and Critical Care, Preethi Hospitals (P) Ltd., Madurai, Tamilnadu, India.
}

\section{PRESENTATION OF CASE}

A 26 year old male presented to the emergency department with alleged history of RTA and sustained run over injury to right lower limb. On examination his vitals were HR-132/min.

BP-70/42 mmHg $\mathrm{SpO}_{2}-97 \%$ with room air. He was papery pale, drowsy and arousable to calls. A provisional diagnosis of severe hypovolemic shock was made. 16G Venflon was secured and resuscitation initiated with crystalloids and colloids. Blood samples sent for routine investigations (CBC, RFT) and blood grouping, typing and coagulation parameters. Meanwhile during resuscitation patient had cardiac arrest with asystole for which CPR initiated and ROSC achieved in 5 minutes. His haemoglobin levels were $5 \mathrm{~g} \%$ with ABG showing mild metabolic and lactic acidosis. He was then stabilised with 3 units of PRBC in ER and shifted to CT scans. In view of ongoing blood loss from the crush injury limb he was taken up for emergency below knee amputation as a life saving measure. In OR Invasive hemodynamic monitoring was done with right IJV and left radial artery cannulation under USG guidance. He was started on norad infusion $0.2 \mathrm{mic} / \mathrm{Kg} / \mathrm{min}$. In OR he had another cardiac arrest and ROSC achieved this time in $4 \mathrm{~min}$. Tourniquet inflated over right lower limb and norad infusion increased to $0.5 \mathrm{mic} / \mathrm{Kg} / \mathrm{min}$. Dopamine infusion was initiated @ 7.5 $\mathrm{mic} / \mathrm{Kg} / \mathrm{min}$. Blood gas analysis done which showed severe metabolic and lactic acidosis ( $\mathrm{pH}$ 6.9) for which soda bicarbonate correction was given. Hb was 6 gm $\%$ for which 5 PRBC, 5 FFP, 5 units platelets transfused. Post operatively he was electively ventilated and his BP remained around 70 systolic. Serial ABG, CVP, IVC diameter measurement were done. Echocardiogram was also done to assess ventricular function which was normal. No septic or anaphylactic aetiology was identified as a cause of the patient's shock. There was no clinical evidence of adrenal insufficiency. After ruling out other causes, vasoplegia was presumed due to prolonged hypotension and cardiac arrest. He was then started on vasopressin infusion 0.04 units/ min. Hydrocortisone infusion $200 \mathrm{mg}$ done over $24 \mathrm{hr}$. After initiating vasopressin and steroid infusion we were able to taper norad infusion with maintaining MAP $>65$ mmHg with adequate CVP and urine output. Patient was extubated on $3^{\text {rd }}$ post op day. Vasopressin infusion was tapered and stopped on $4^{\text {th }}$ POD. Steroid infusion was stopped on $3^{\text {rd }}$ POD and oral supplementation of prednisolone started.

The incidence of post-operative vasoplegia following on-pump cardiac surgery

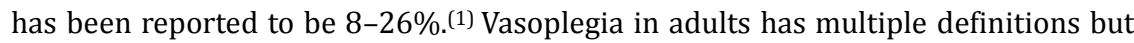
commonly defined as a normal or high output state (cardiac index $>2.2 \mathrm{~L} / \mathrm{min} / \mathrm{sq} \mathrm{m}$ ) with difficulty maintaining a MAP of $60 \mathrm{mmHg}$ due to a low SVR $(<800$ dynes.sec/cms) despite high dose vasopressor (typically $0.5 \mathrm{mic} / \mathrm{Kg} / \mathrm{min}$ ) of norepinephrine equivalents.

On pump CABG, female sex, non-elective surgery, pre-operative ACE inhibitors, $\mathrm{EF}<35 \%$, increased $\mathrm{BMI}$ were independent predictors of post-operative vasoplegia.(2)

\author{
Corresponding Author: \\ Dr. Suresh J., \\ Preethi Hospitals (P) LTD., \\ \#50, Melur Main Road, \\ Uthangudi, Madurai-625107, \\ Tamilnadu, India. \\ E-mail: sureshchills03@gmail.com
}

DOI: $10.14260 / \mathrm{jemds} / 2020 / 267$

Financial or Other Competing Interests: None.

How to Cite This Article:

Suresh J, Balaji T, Santhosh $V$, et al. Refractory hypotension after successful cardiac arrest resuscitation- time to rule out vasoplegic syndrome. J. Evolution Med. Dent. Sci. 2020;9(14):1229-1231, DOI: 10.14260/jemds/2020/267

Submission 05-02-2020,

Peer Review 17-03-2020,

Acceptance 23-03-2020,

Published 06-04-2020. 


\section{DISCUSSION}

Vasoplegic shock, synonymous with distributive shock is a more significant circulatory perturbation that is best described as vasoplegia with evidence of tissue hypoperfusion which may be accompanied with hyperlactatemia.(3) The vasoplegic syndrome occurring in early post-operative period of cardiac surgeries is characterised by a severe hypotension, with decreased SVR, decreased arteriolar reactivity and increased requirements for filling volume and vasopressive agents despite adequate cardiac output. From the literature, vasoplegic syndrome has been closely associated with low left ventricular ejection fraction and heart failure syndrome.(4) The renin angiotensin system may play an important role in vascular tone changes during the post-operative period.(5)

The pathophysiology of vasoplegic syndrome revolves around systemic vascular resistance (SVR), which is determined by changes in arteriolar diameter, controlled by the contractile activity of the vascular smooth muscle cell in the tunica media. Vascular tone is regulated by intrinsic mediator \{endothelial secretions (nitric oxide, prostacyclin, endothelin), vasoactive metabolites (acidosis, hypoxia, hydrogen peroxide)\} and extrinsic mechanism which is mediated by sympathetic control and vasoactive hormones which include adrenaline, angiotensin II and vasopressin.(6) Vascular hyporeactivity associated hypotension is clearly associated with mortality.

The presence of raised lactate portends a particularly grave prognosis in the presence of shock. The commonest cause of vasoplegia is sepsis followed by cardiac surgeries. Burns, trauma are conditions associated with significant tissue injury with consequent hypermetabolism, systemic inflammation and predisposition to developing organ dysfunction. Vasoplegia could be considered to be one such organ dysfunction.(7) Norepinephrine is a very potent and reliable vasopressor which increases mean arterial pressure without any concomitant increases in heart rate. In contrary to epinephrine, norepinephrine does not act on beta 2 adrenergic receptors hence lactate levels do not increase and may be used to guide resuscitation. ${ }^{(8)}$

Adrenergic vasopressors have potential side effects such as increased oxidative stress, modulation of inflammatory response, interaction with cellular energy metabolism.(9) A new concept has emerged called decatecholaminization, which consists in using non-catecholamine vasopressors to decrease catecholamine exposure.(10) The rationale for vasopressin use is that there is a relative vasopressin deficiency in septic shock such that addition of exogenous vasopressin restores vascular tone by acting on non-adrenergic receptors, increases blood pressure, thereby reducing norepinephrine requirements, and possibly has favourable effects on cytokine production.(11)

Phenylephrine is a pure alpha 1 agonist for which clinical trial data are limited. It has the potential to produce splanchnic vasoconstriction. Other alternatives which are futuristic drugs include selepressin and angiotensin II.(12) Methylene blue counteract the effect of increased nitric oxide synthase stimulation. It can be used for treating vasoplegia after cardiac surgeries, drug poisoning, anaphylactic shock, post reperfusion syndrome after liver transplantation.(13) Currently data are insufficient to propose methylene blue as first agent.

Glucocorticoids restores vascular responsiveness to vasopressors through non-genomic inhibition of arachidonic acid and inhibition of synthesis of inducible nitric oxide synthase and cyclooxygenase and increase in alpha adrenergic receptor gene expression.(14) Hydroxocobalamin is a highly bioavailable form of vitamin B12. Proposed mechanism of the drug may include the NO system like that of methylene blue as well as a second mechanism involving hydrogen sulphide $\left(\mathrm{H}_{2} \mathrm{~S}\right)$-induced vasodilation.(15)

Other experimental treatment modalities include modulation of sympathetic system with alpha 2 agonist, selective beta 1 blockade and adrenomedullin blockade.(16) Optimal vasopressor therapy consists of a combining agents acting on different receptors while minimising dose of each agent and possibly increasing overall safety. The combination of noradrenaline and vasopressin allowed a decrease in total noradrenaline dose.

In our case vasoplegia occurred due to severe hypovolemia and consequent cardiac arrest. After ROSC even with adequate fluid and blood transfusion which was assessed using serial ABG CVP, IVC diameter measurement vasoplegia remained for several days requiring high dose noradrenaline, vasopressin and steroid infusion. Due to non-availability of cardiac output monitor we could not estimate cardiac index and systemic vascular resistance. In this case we could able to taper high dose noradrenaline infusion after introducing vasopressin and steroid infusion hence methylene blue was not tried. Hemodynamic parameters like MAP improved significantly after these infusion paving way for us to conclude it as a vasoplegic syndrome. Subsequent surgeries including wound debridement and stump closure were done under USG guided lumbar plexus and sciatic nerve block. He was discharged in stable condition on $17^{\text {th }}$ post-operative day.

\begin{tabular}{|c|c|c|c|}
\hline Specimen & Test Description & Result / Units & Reference Range \\
\hline \multicolumn{4}{|c|}{ BIOCHEMISTRY } \\
\hline \multicolumn{4}{|c|}{ ABG } \\
\hline BLOOD & $\begin{array}{l}\text { PH } \\
\text { GEM } 3500\end{array}$ & 6.9 & $7.3-7.4$ \\
\hline BLOOD & $\begin{array}{l}\text { PCO2 } \\
\text { GEM } 3500\end{array}$ & $33 \mathrm{mmHg}$ & $35-48$ \\
\hline BLOOD & $\begin{array}{l}\text { PO2 } \\
\text { GEM } 3500\end{array}$ & $439 \mathrm{mmHg}$ & $83-108$ \\
\hline BLOOD & $\begin{array}{l}\text { NAt } \\
\text { GEM } 3500\end{array}$ & $140 \mathrm{mmol} / \mathrm{L}$ & $136-145$ \\
\hline BLOOD & $\begin{array}{l}\text { K+ } \\
\text { GEM } 3500\end{array}$ & $2.0 \mathrm{mmol} / \mathrm{L}$ & $3.4-4.5$. \\
\hline BLOOD & $\begin{array}{l}\text { CA++ } \\
\text { GEM } 3500\end{array}$ & $0.8 \mathrm{mg} / \mathrm{gL}$ & $1.15-1.35$ \\
\hline BLOOD & $\begin{array}{l}\text { Glucose } \\
\text { GEM } 3500\end{array}$ & $151 \mathrm{Mg} / \mathrm{dl}$ & $60-95$ \\
\hline Plasma & $\begin{array}{l}\text { LACTATE } \\
\text { SPCTROPHOTOMETRY }\end{array}$ & $>15.0 \mathrm{mg} / \mathrm{dL}$ & $4.5-19.8$ \\
\hline BLOOD & $\begin{array}{l}\text { Hct } \\
\text { GEM } 3500\end{array}$ & $19 \%$ & \\
\hline BLOOD & $\begin{array}{l}\text { HCO- } \\
\text { GEM } 3500\end{array}$ & $7.8 \mathrm{mmol} / \mathrm{L}$ & \\
\hline BLOOD & $\begin{array}{l}\text { TCO2 } \\
\text { GEM } 3500\end{array}$ & $8.8 \mathrm{mmol} / \mathrm{L}$ & \\
\hline BLOOD & $\begin{array}{l}\text { BE(B) } \\
\text { GEM } 3500\end{array}$ & 21 & $\mathrm{mmol} \mathrm{h}$ \\
\hline BLOOD & $\begin{array}{l}\text { SO2C } \\
\text { GEM } 3500\end{array}$ & $100 \%$ & \\
\hline$B 1000$ & $\begin{array}{l}\text { THb } \\
\text { GEM } 3500\end{array}$ & $5.9 \mathrm{gldl}$ & $11.7 \cdot 17.4$ \\
\hline & & G Report & \\
\hline
\end{tabular}




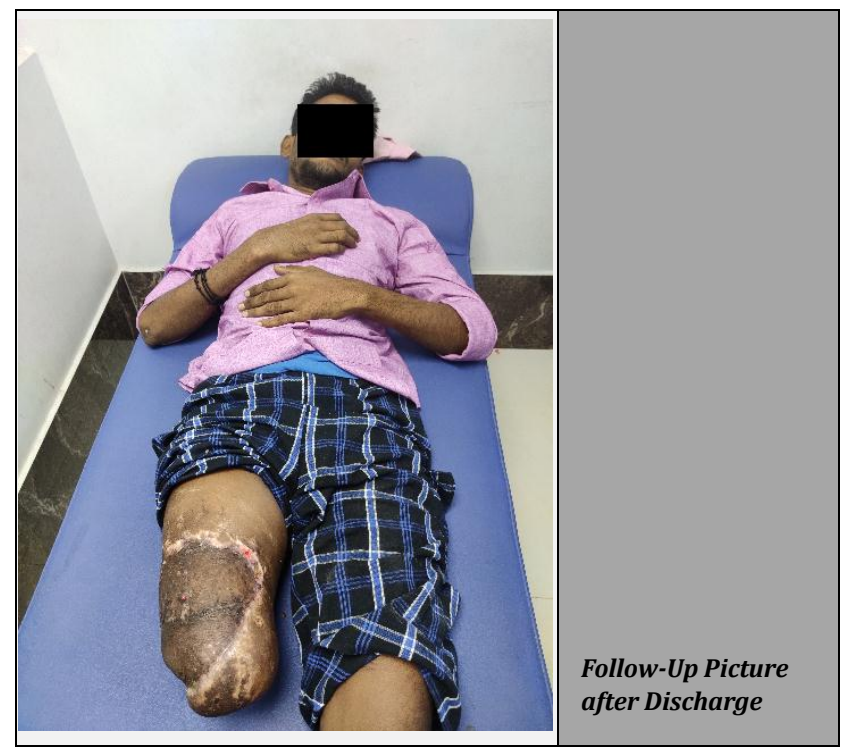

CONCLUSIONS

Vasoplegia is a common feature of all advanced shock states, with noradrenaline remaining the main stay of vasoplegia induced hypotension. Though vasoplegia is seen commonly in sepsis, post cardiac surgeries, it should be considered in trauma and post cardiac arrest patients with refractory hypotension despite adequate fluid and blood product resuscitation. Usage of cardiac output monitor serves as a better tool to assess indices like SVR, CI. Early recognition and aggressive management of vasoplegia is necessary to prevent mortality in such cases. It is time to move from a standardized therapy with noradrenaline alone to a multimodal strategy.

\section{REFERENCES}

[1] Sun X, Zhang L, Hill PC, et al. Is incidence of postoperative vasoplegic syndrome different between off-pump and onpump coronary artery bypass grafting surgery? Eur J Cardiothorac Surg 2008;34(4):820-5.

[2] Jentzer JC, Vallabhajosyula S, Khanna AK, et al. Management of refractory vasodilatory shock. Chest 2018;154(2):416-26.

[3] Tuman KJ, McCarthy RJ, O'Connor CJ, et al. Angiotensinconverting enzyme inhibitors increase vasoconstrictor requirements after cardiopulmonary bypass. Anesth Analg 1995;80(3):473-9.

[4] Vincent JL, De Backer D. Circulatory shock. N Engl J Med 2013;369(18):1726-34.

[5] Argenziano M, Chen JM, Choudhri AF, et al. Management of vasodilatory shock after cardiac surgery: identification of predisposing factors and use of a novel pressor agent. J Thorac Cardiovasc Surg 1998;116(6):973-80.

[6] Taylor KM, Bain WH, Russell M, et al. Peripheral vascular resistance and angiotensin II levels during pulsatile and non-pulsatile cardiopulmonary bypass. Thorax 1979;34(5):594-8.

[7] Varpula M, Tallgren M, Saukkonen K, et al. Hemodynamic variables related to outcome in septic shock. Intensive Care Med 2005;31(8):1066-71.

[8] Levy B, Gibot S, Franck P, et al. Relation between muscle $\mathrm{Na}+\mathrm{K}+\mathrm{ATPase}$ activity and raised lactate concentrations in septic shock: a prospective study. Lancet 2005;365(9462):871-5.

[9] Hartmann C, Radermacher P, Wepler M, et al. Nonhemodynamic effects of catecholamines. Shock 2017;48(4):390-400.

[10] Asfar P, Chawla L, Lerolle N, et al. Angiotensin-II: more than just another vasoconstrictor to treat septic shockinduced hypotension? Crit Care Med 2014;42(8):1961-3.

[11] Russell JA, Fjell C, Hsu JL, et al. Vasopressin compared with norepinephrine augments the decline of plasma cytokine levels in septic shock. Am J Respir Crit Care Med 2013;188(3):356-64.

[12] Levy B, Fritz C, Tahon E, et al. Vasoplegia treatments: the past, the present, and the future. Crit Care 2018;22(1):52.

[13] Hosseinian L, Weiner M, Levin MA, et al. Methylene blue: magic bullet for vasoplegia? Anesth Analg 2016;122(1):194-201.

[14] Sakaue M, Hoffman BB. Glucocorticoids induce transcription and expression of the alpha $1 \mathrm{~B}$ adrenergic receptor gene in DTT1 MF-2 smooth muscle cells. J Clin Invest 1991;88(2):385-9.

[15] Mustafa AK, Sikka G, Gazi SK, et al. hydrogen sulfide as endothelial derived hyperpolarizing factor sulfhydrates potassium channels. Circ Res 2011;109(11):1259-68.

[16] Marino R, Struck J, Maisel AS, et al. Plasma adrenomedullin is associated with short-term mortality and vasopressor requirement in patients admitted with sepsis. Crit Care 2014;18(1):R34. 